\title{
MICRONUCLEUS IN EXFOLIATED BUCCAL CELLS OF CHILDREN FROM DURANGO, MEXICO, EXPOSED TO ARSENIC THROUGH DRINKING WATER
}

\author{
Olga Dania LÓPEZ GUZMÁN ${ }^{1}$, Rogelio COSTILLA SALAZAR ${ }^{2}$, Nadia PELALLO MARTÍNEZ ${ }^{3}$, \\ Yolanda ALCARAZ CONTRERAS ${ }^{4}$, Melissa BOCANEGRA SALAZAR ${ }^{5}$ y \\ Diana Olivia ROCHA AMADOR ${ }^{4 *}$
}

\footnotetext{
${ }^{1}$ Facultad de Ciencias Químicas, Universidad Juárez del Estado de Durango. Avenida Veterinaria, Durango, Durango, México, C. P. 34120

${ }^{2}$ Departamento de Ciencias Ambientales, División de Ciencia de la Vida, Universidad de Guanajuato. Carretera Irapuato-Silao, kilómetro 9, Irapuato, Guanajuato, México, C. P. 36500

${ }^{3}$ Universidad del Centro de México. Capitán Caldera 75, Colonia Tequixquiapan, San Luis Potosí, San Luis Potosí, México, C. P. 78250

${ }^{4}$ Departamento de Farmacia, División de Ciencias Naturales y Exactas, Universidad de Guanajuato. Noria Alta, Guanajuato, Guanajuato, México, C. P. 36050

${ }^{5}$ Facultad de Ciencias Forestales, Universidad Juárez del Estado de Durango. Río Papaloapan y Bulevar Durango, Durango, Durango, México, C. P. 34120

*Corresponding author: olivia2000_mx@hotmail.com
}

(Received February 2016; accepted September 2016)

Key words: genotoxicity, natural pollution, vulnerable population, environmental risk

\begin{abstract}
Exposure to inorganic arsenic (As) via drinking water in Latin America and Mexico is a growing public health concern that requires rapid methods to assess risk and adverse effects. The measurement of micronucleus frequency (MNf) in oral mucosa is a noninvasive and low-cost method for monitoring the genotoxic damage in exposed populations. Mexican children from Durango city, a zone with high water arsenic concentrations, were selected and assigned to three-risk categories (low, medium, high) based on the use of tap or bottled water. Levels of As in water, urine and MNf, were measured. Results indicate a significant correlation between the groups at risk and the frequency of MNf in children $(0.9 \pm 1.9 \mathrm{MN}, 1.1 \pm 1.9$, and $2.6 \pm 2.2$ per 1000 buccal cells, respectively); $(\mathrm{r}=$ $0.416 ; \mathrm{p}=0.001)$. Which demonstrated that the MNf in oral mucosa is an efficient and low-cost technique for assessing and monitoring DNA damage by exposure to As. This study also provides evidence that the modification of risk factors could reduce health risk.
\end{abstract}

Palabras clave: genotoxicidad, contaminación natural, población vulnerable, riesgos ambientales

\section{RESUMEN}

La exposición a arsénico (As) inorgánico a través del agua de bebida es un problema de salud pública en América Latina y en México que requiere métodos rápidos para evaluar riesgo y efectos adversos. La medición de la frecuencia de micronúcleos (MNf) en mucosa oral es un método no invasivo y de bajo costo para monitorear daño genotóxico en población expuesta a contaminantes ambientales. Para esta investigación, 
fueron seleccionados niños mexicanos de la ciudad de Durango, una zona con altas concentraciones de As en agua, y asignados en tres categorías de riesgo (baja, media y alta) con base en el uso de agua de la llave o agua embotellada. Se midieron los niveles de As en agua, orina y la MNf. Los resultados indican una correlación significativa entre los grupos de riesgo y la frecuencia de $\mathrm{MNf}$ en los niños $(0.9 \pm 1.9 \mathrm{MN}, 1.1 \pm 1.9$, y $2.6 \pm$ 2.2 por 1000 células bucales, respectivamente); $(\mathrm{r}=0.416 ; \mathrm{p}=0.001)$. Estos resultados demuestran que la MNf en mucosa oral es una técnica eficiente y de bajo costo para evaluar y monitorear daño al ADN por la exposición a As. Este estudio también provee evidencia de que la modificación de factores de riesgo puede reducir riesgos a la salud.

\section{INTRODUCTION}

Arsenic (As) is a natural component of the earth's crust and is widely distributed throughout the environment. Areas known to have high As concentrations are located in Argentina, Mexico, Chile, Finland, Bangladesh, and China. The World Health Organization (WHO) has stated that exposure to inorganic As via drinking water is a growing public health concern. The adverse effects caused by longterm exposure to inorganic As through drinking water have been widely studied. The effects reported include skin lesions, diabetes mellitus, degenerative effects on the circulatory system, and neurotoxicity (Abernathy et al. 1999, Rocha-Amador et al. 2007, States et al. 2009, Huang et al. 2011) as well as certain types of skin, urinary tract, liver, and lung cancers (Tapio and Grosche 2006, Coronado-Gonzalez et al. 2007, Celik et al. 2008, IARC 2012).

Arsenic (As) is a clastogenic and aneugenic agent (Tapio and Grosche 2006, Chakraborty and De 2009, IARC 2012); aneuploidy and clastogenicity have been proposed as cytogenetic assays in risk assessment as the first step towards evaluating cancer risk (Bonassi et al. 2007, Thomas et al. 2009). The frequencies of $\mathrm{MN}$ in exfoliated buccal epithelial cells have been used for cancer screening and biomonitoring of genotoxic effects in humans exposed to As (Martínez et al. 2005, Chakraborty et al. 2006, Ghosh et al. 2008, Bartolotta et al. 2010). They serve as an appropriate index to monitor the genotoxicity induced by As thanks to the fact that the cells are in direct contact with the carcinogen. Lower concentrations of contaminants from those described for adults, may have damaging toxic effects for a child if exposure occurs in a stage of biological vulnerability, where adverse effects could manifest later in life (EPA 2006). Children are more vulnerable to the toxicity of contaminants due to their developmental processes involving physiologic and metabolic maturation, as well as to behavioral aspects that constitute critical windows of development. Furthermore, their exposure pathways and habits may also be different than the adults, which may lead to increase the risk (Neri et al. 2003, Holland et al. 2011).

Durango City drinking water is provided by wells from El Valle del Guadiana aquifer. In recent years, high levels of As concentration have been detected in drinking water sources of El Valle del Guadiana (Arreguín et al. 2005, Alarcón et al. 2013). One way of controlling the risk is by substituting the use of tap water with As-free bottled water. The aim of this research was to determine whether the substitution of tap water by bottled water would decrease the risk of genotoxicity in children who live in the City of Durango by using the micronucleus test in oral exfoliated cells.

\section{METHODS}

\section{Study population}

A cross-sectional study was designed to encompass children, ages from 5 to 12, from three elementary schools in Durango City, Mexico. Study participants were all born and raised in the area of analysis. A questionnaire was used to gather information on their health status and on any risk factors that might influence the biomarkers tested for exposure and effect. A total of 91 children were included after informed consent was obtained from each participant's parent or legal guardian. The study protocol was approved by the appropriate Committee for the Protection of Human Participants by the Universidad Juárez from Durango State.

\section{Collection of environmental and biological samples}

Urine and exfoliated buccal samples were collected on the same day. A tap water sample (AsW) was also collected. Tap water and urine samples were collected in polyethylene bottles. The buccal cell samples were obtained with a sterile brush from both cheeks and placed in tubes containing $10 \mathrm{~mL}$ of 
buffer solution (0.1M EDTA, $0.01 \mathrm{M}$ Tris- $\mathrm{HCl}, 0.02 \mathrm{M}$ $\mathrm{NaCl}$ at $\mathrm{pH}$ 7). All samples were stored at $4{ }^{\circ} \mathrm{C}$ until analysis. Bottled water consumption was determined by means of a questionnaire.

\section{Determination of As in water (AsW) and urine (AsU)}

Before the analysis, the $5 \mathrm{~mL}$ urine samples were digested at $70{ }^{\circ} \mathrm{C}$ with a mixture of $\mathrm{HNO}_{3}: \mathrm{HCIO}_{4}$ $1: 6$. Water and urine samples were reduced for 5 min at $80{ }^{\circ} \mathrm{C}$ with $\mathrm{KI} 10 \%$, ascorbic acid $5 \%$, and $\mathrm{HCl}$. Arsenic s was analyzed using an atomic absorption spectrophotometer coupled to a hydride system (Perkin-Elmer, model AAnalyst 100). For quality control, reference standard ClinChek ${ }^{\circledR}$ Urine Control lyophilized for trace elements of IRIS Technologies was analyzed. The accuracy was $97 \pm 6 \%$. Levels of $\mathrm{AsU}$ were adjusted for specific gravity.

Distilled-deionized water was used for all analytical work; also, glassware and other materials were soaked in $10 \%$ nitric acid, rinsed with doubly distilled water, and dried before use.

\section{Determination of micronucleus frequency (MNf)}

The samples were stained the day of collection. The exfoliated buccal samples were washed three times with buffer solution followed by centrifugation at $1500 \mathrm{rpm}$ for $10 \mathrm{~min}$. After the final wash, the cell suspension was placed into $2 \mathrm{~mL}$ of buffer solution. $50 \mu \mathrm{L}$ of cell suspension were dropped into a slide preheated to $37{ }^{\circ} \mathrm{C}$. The slides were stained with Giemsa at $10 \%$ and stored at ambient temperature until use. Three slides were prepared for each subject. Micronucleus frequency (MNf) was evaluated scoring 1000 cells if less than 5 micronucleated cells were observed after counting 1000 cells, additional 1000 cells were scored, and so on, up to a maximum cell count of 3000 cells according to Tolbert et al. (1991). The frequency was expressed in MN per 1000 cells.

\section{Risk group}

Three risk groups were created and categorized as follows, based on their use of tap or bottled water to drink or cook: 1) Low risk: children in homes where bottled water is used for drinking and cooking; 2) Medium level: children in homes where tap water is used for drinking and bottled water for cooking or vice versa; and 3) High risk: children in homes where tap water is used for drinking and cooking. AsU concentrations were determined to verify differences among the risk groups, as indicated above.

\section{Other risk factors}

Questions were made regarding risk factors occurring three weeks previous to sample collection, like visits to the dentist, diseases, and pharmaceutical treatments, as well as exposure to tobacco smoke, $\mathrm{X}$-ray, herbicides, solvents, and pesticides (Thomas et al. 2009).

\section{Statistical analysis}

Descriptive and exploratory data analysis for continuous variables (age, MNf, AsW, AsU) and a descriptive analysis with respect to categorical variables (gender, risk factors, exposure) were done. MNf, AsW and AsU do not assumed normal distribution. The variables $\mathrm{MNf}, \mathrm{AsW}$ and $\mathrm{AsU}$ were $\log 10$-transformed and reported as geometric mean and standard deviation. A Spearman correlation was calculated using MNf, AsU, and Risk categories. Non-parametric analysis (Kruskal-Wallis and Mann Whitney U Test) was applied to compare differences among risk groups. The statistical analyses were carried out using SPSS statistical software package version 19.0, while categorical variables were analyzed by EPIDAT version 3.1.

\section{RESULTS AND DISCUSSION}

Diverse studies have established that the use of tap water in zones of arsenic poisoning increases the level of exposure to this toxic and, consequently, leads to adverse health impacts. Buccal mucosa represents a barrier for carcinogens that can be metabolized and can potentially generate reactive products. Close to $90 \%$ of all cancers, seem to originate in epithelial cells. Lung, skin, bladder, kidney and ureter cell carcinoma have been associated with As (Tapio and Grosche 2006). For this reason, the evaluation of buccal epithelia may be used to monitor genotoxic events, particularly those carcinogens that enter the body through inhalation or ingestion such as As.

This study was carried out in a zone with high concentrations of arsenic in tap water. General characteristics of each risk group are shown in table $\mathbf{I}$. No significant differences in age, gender, and water intake were observed among groups $(p=0.24$; $\mathrm{p}=0.33 ; \mathrm{p}=0.33$, respectively). According to the established criteria on the use of bottled or tap water for drinking or cooking, it was found that $55 \%$ of the children were in the high risk group and $24 \%$ and $16 \%$ in the medium and low risk groups respectively. We measured As in tap water samples (AsW) for each child evaluated. No significant differences 
TABLE I. GENERAL CHARACTERISTICS OF EACH RISK GROUP

\begin{tabular}{lcccc}
\hline & Low risk & Medium risk & High risk & P value \\
\hline Sample size & 15 & 26 & 50 & \\
Age (years) $)^{\mathrm{a}}$ & $\begin{array}{c}7.6 \pm 1.3 \\
(6-11)\end{array}$ & $\begin{array}{c}8.1 \pm 1.7 \\
(6-12)\end{array}$ & $\begin{array}{c}7.5 \pm 1.4 \\
(5-11)\end{array}$ & $0.24^{\mathrm{b}}$ \\
& & & & \\
\hline Gender & $8(53.3)$ & $10(38.5)$ & $28(56)$ & $0.33^{\mathrm{c}}$ \\
\hline Boys n (\%) & $7(46.7)$ & $16(61.5)$ & $22(44)$ & \\
Girls n (\%) & $1.3 \pm 0.6$ & $1.2 \pm 0.4$ & $1.1 \pm 0.5$ & $0.57^{\mathrm{b}}$ \\
Water intake (L/day) & $(0.5-2.0)$ & $(0.5-2.0)$ & $(0.25-2.5)$ & \\
\hline
\end{tabular}

${ }^{a}$ Values are arithmetic mean \pm standard deviation (minimum-maximum), ${ }^{\mathrm{b}}$ differences between means were tested by ANOVA, ${ }^{\mathrm{c}}$ differences between proportions were evaluated by $\chi^{2}$ test

were detected between AsW levels between the three risk groups $(\mathrm{p}=0.24)$. All AsW samples of the three groups were above the WHO guidelines for drinking water $(10 \mu \mathrm{g} / \mathrm{L})$, Low risk: $40.5 \pm 16.4$, Medium risk: $49.5 \pm 18.6$, High risk: $46.2 \pm 17.6 \mu \mathrm{g} / \mathrm{L}$. Also $87.1 \%$, $92.9 \%$, and $81.8 \%$ of the samples of all risk groups exceeded the Mexican standard for drinking water (NOM-127-SSA-1991) of $25 \mu \mathrm{g}$ (SSA 1991). The highest value was 7 and 3 times higher than the limits provided by the WHO and the NOM-127 respectively (Fig. 1). These results proved that the whole population evaluated would be at risk of exposure to As via drinking water if they used only tap water.
Urine As (AsU) levels were determined to assess whether the risk of exposure and its effects could be modified with the use of bottled water (without As) to cook and drink. The geometric mean values of AsU levels were $55.5 \pm 23.5 ; 85.6 \pm 55.8$, and $107.8 \pm 47.2 \mu \mathrm{g} / \mathrm{L}$, in each assigned risk group (Fig. 1). A significant difference of AsU levels was observed among risk groups $(\mathrm{p}<0.001$; Kruskal Wallis test). Risk groups were compared by pairs for AsU levels using the Mann Whitney U test and significant differences were found between high vs low risk $(\mathrm{p}<0.001)$ and high vs medium risk $(\mathrm{p}<0.05)$ groups; a marginal significance $(\mathrm{p}=0.054)$

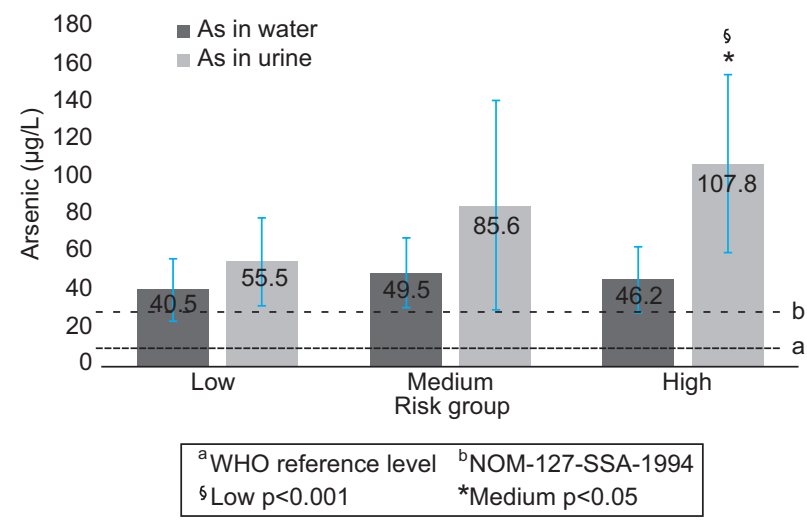

Fig. 1. As levels in tap water $(\mu \mathrm{g} / \mathrm{L})$ and urine $(\mu \mathrm{g} / \mathrm{L})$ in each assigned risk group. Risk groups were created according to tap water use. Arsenic in water (AsW) and arsenic in urine (AsU) levels are reported like geometric mean \pm standard deviation (error bars in graphic), ${ }^{a} 10 \mathrm{mg} / 1$ WHO reference level, b 25 mg/1 NOM-127-SSA-1994, $\S$ Significative Spearman correlation among assigned risk group and $\mathrm{AsU}(\mathrm{r}=0.457 ; \mathrm{p}<0.001),{ }^{*} \mathrm{AsU}$ levels of high risk group were significantly different compared with medium $(\mathrm{p}<0.05)$ and low risk groups $(\mathrm{p}<0.001)$, Mann Whitney U test. 
TABLE II. MICRONUCLEUS FREQUENCY (MNF) IN EACH RISK GROUP

\begin{tabular}{|c|c|c|c|}
\hline & $\begin{array}{c}\text { Low risk } \\
\mathrm{n}=15\end{array}$ & $\begin{array}{c}\text { Medium risk } \\
\mathrm{n}=26\end{array}$ & $\begin{array}{l}\text { High risk } \\
\mathrm{n}=50\end{array}$ \\
\hline $\mathrm{MNf} / 1000$ buccal cells & $0.9(0-6)$ & $1.1(0-8)$ & $2.6(0-9)^{\text {ad } \neq}$ \\
\hline$\%>1.1 \mathrm{MN} / 1000$ buccal cells $^{\mathrm{b}}$ & 13.3 & 30.8 & 64 \\
\hline$\%>4 \mathrm{MN} / 1000$ buccal cells ${ }^{\mathrm{c}}$ & 13.3 & 7.7 & 16 \\
\hline
\end{tabular}

${ }^{\mathrm{a}}$ Values are geometric mean (minimum-maximum), ${ }^{\mathrm{b}} \mathrm{MNf}$ observed in young adult $\left(0.3 \pm 0.8 \mathrm{MN}\right.$ per 1000 cells), ${ }^{\mathrm{c}}$ Abnormal MNf observed in young adult (4 MN per 1000 cells ), d Significant differences between means $(\mathrm{p}<0.05$; Kruskal-Wallis test), ${ }^{\ddagger}$ Significant differences compared with medium and low risk $(\mathrm{p}<0.05$; Mann Whitney U test)

was found between medium vs low risk groups. These results clearly indicate that if bottled water is used to drink or cook (low and medium risk group), the exposure is significantly less than if only tap water is consumed (high risk group).

The marginal significance $(p=0.054)$ between low and medium risk group in AsU levels could have occurred because the sample size of the low risk category was smaller $(n=15)$ than the other groups. These results are reasonable in an area where more than $50 \%$ of the people use only tap water for their everyday consumption. An increased sample size would probably prove it.

In addition, a significant Spearman correlation was found between the assigned risk groups and $\mathrm{AsU}$ levels, the group at highest risk presenting the highest levels of AsU ( $r=0.457 ; p<0.001)$. This association between habits in water consumption and the levels of AsU demonstrated that the risk of exposure to As is modifiable and it could mark a difference in the level of exposure.

The levels of genotoxic damage found in this study were similar to those obtained in studies on adult populations in Mexico, Argentina, and Asia where a high number of micronucleated cells were observed in individuals who had been exposed to different concentrations of $\mathrm{AsW}$, in comparison to control groups (Gonsenbatt et al. 1997, Basu et al. 2002, Chakraborty et al. 2006, Bartolotta et al. 2010). Micronucleus frequency (MNf) per 1000 buccal cells is shown in table II. MNf per group was $0.9 \pm 1.9$ $\mathrm{MN}, 1.1 \pm 1.9$, and $2.6 \pm 2.2$ per 1000 buccal cells, respectively.

In the last few years there have been increasing numbers of studies with child populations that have used the micronucleus frequency as biomarker for genotoxic damage, principally based on the supposition that children are more susceptible to toxic agents than adults. In addition, recent studies suggest that high frequencies of cells with clastogenic effects in this population can predict cancer in healthy adults (Bonassi et al. 2004). The geometric mean of MNf observed in the high risk group was $2.6 \pm 2.2$ per 1000 buccal cells. In this group $64 \%$ of the samples were similar to MNf observed in young adults $(0.3 \pm 0.8$ per 1000 cells) and $16 \%$ similar to abnormal MNf observed in young adults ( 4 per 1000 cells) (Thomas et al. 2009). Also, these values are higher than the previously report by Montero et al. (2003) in buccal epithelium of adolescents living in México City. Montero reported a mean of $0.57 \mathrm{MNf}$ in subjects evaluated (11-16 years old).

An interesting finding of the present study is the relationship between risky conducts and a genotoxic effect. The total population presented general characteristics of exposure to tap water and similar potential risks. However, by assigning the population to three groups at different levels of risk, a significant (Spearman) correlation was found $(\mathrm{r}=0.416 ; \mathrm{p}<$ 0.001 ) between the MNf and the risk group (Fig. 2).

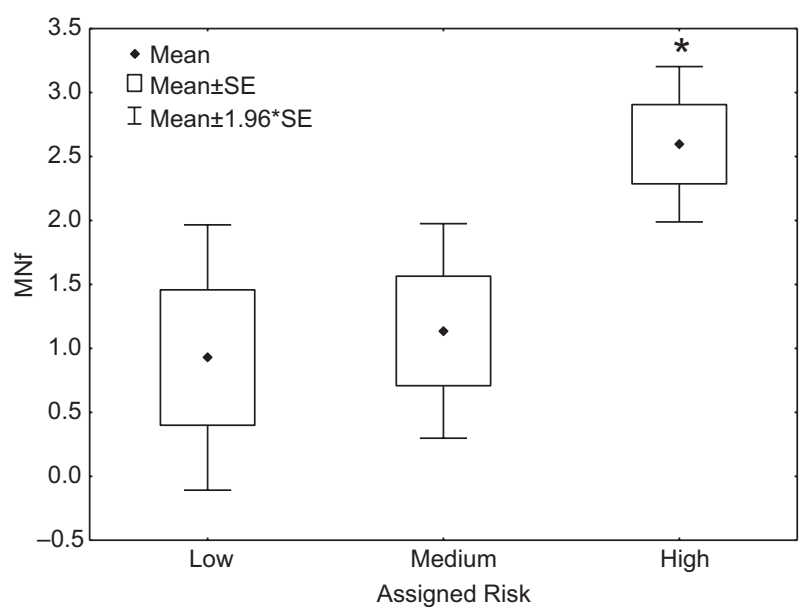

Fig. 2. Mean of micronucleus frequency (MNf) in each assigned risk group. Standard error (SE). Significative Spearman correlation among assigned risk and $\mathrm{MNf}(\mathrm{r}=0.416$; $\mathrm{p}$ $<0.001)$, *significantly different compared with medium and low risk $(\mathrm{p}<0.05$; Mann Whitney $\mathrm{U}$ test $)$ 
TABLE III. PRESENCE OF RISK FACTORS THREE WEEKS PRIOR TO THE STUDY IN EACH ASSIGNED RISK GROUP

\begin{tabular}{lcccc}
\hline & $\begin{array}{c}\text { Low risk } \\
\text { (yes/no) }\end{array}$ & $\begin{array}{c}\text { Medium risk } \\
\text { (yes/no) }\end{array}$ & $\begin{array}{c}\text { High risk } \\
\text { (yes/no) }\end{array}$ & P value \\
\hline Dentist visit & $5 / 10$ & $3 / 23$ & $4 / 46$ & $0.05^{\mathrm{a}}$ \\
Disease presence & $4 / 11$ & $5 / 21$ & $10 / 40$ & $0.8^{\mathrm{a}}$ \\
Pharmacological treatment & $2 / 13$ & $4 / 22$ & $9 / 41$ & $0.9^{\mathrm{a}}$ \\
Tobacco smoke exposure & $2 / 13$ & $9 / 17$ & $16 / 34$ & $0.3^{\mathrm{a}}$ \\
X-ray exposure & $0 / 15$ & $0 / 26$ & $1 / 49$ & $0.7^{\mathrm{a}}$ \\
Herbicide exposure & $1 / 14$ & $4 / 22$ & $3 / 47$ & $0.4^{\mathrm{a}}$ \\
Solvents exposure & $1 / 14$ & $1 / 25$ & $5 / 45$ & $0.6^{\mathrm{a}}$ \\
Pesticide exposure & $0 / 15$ & $2 / 24$ & $3 / 47$ & $0.6^{\mathrm{a}}$ \\
\hline
\end{tabular}

${ }^{a}$ Differences between proportions were evaluated by $\chi^{2}$ test

Additionally, a significant difference of MNf was observed among groups $(\mathrm{p}<0.001$; Kruskal-Wallis test), which was further analyzed by group pairs with Mann Whitney U test: Low vs Medium risk were not different $(p=0.47)$; Low vs High risk and Medium vs High risk showed a significant difference $(\mathrm{p}<0.001$; $\mathrm{p}<0.05$, respectively). This indicates a higher genotoxic risk if only tap water is used.

Other risk factors for genotoxic damage in the three weeks prior to the study were also evaluated (Table III). These included: dentist visits, disease and pharmacological treatment, as well as exposure to tobacco smoke, X-ray, pesticides, herbicides and solvents. Only a significant difference within groups in the risk factor of dentist visits $(\mathrm{p}<0.05)$ was observed, nevertheless the children of the low risk group had the most number of dentist visits.

The present study, to our knowledge, is the first one using MNf in buccal mucosa of children as a biomarker of effect associated with the risk of exposure to As due to the source of drinking water.

So, this study provides evidence that a risky habit, the use of tap water for cooking or drinking, may modify the exposure as much as the effect. This implies that intervention protocols could be implemented in zones with high concentrations of arsenic in the water supply, regarding the use of bottled water in order to prevent the risk of exposure of the population.

\section{CONCLUSION}

This study reaffirms the utility of the exfoliated buccal cell MN test as a sensitive biomarker of effects due to exposure to As. It is an economical and noninvasive method that can be used to evaluate effects associated to risky conducts in child populations. This study also provides evidence that the modification of risk factors, in this case through the use of bottled water in zones of endemic high concentrations of arsenic in the water supply, may effectively reduce the risk to child health.

\section{REFERENCES}

Abernathy C.O., Liu Y.P., Longfellow D., Aposhian H.V., Beck B., Fowler B., Goyer R., Menzer R., Rossman T., Thompson C. and Waalkes M. (1999). Arsenic: health effects, mechanisms of actions, and research issues. Environ. Health Perspect. 107 (7), 593-7.

Alarcón-Herrera M.T., Bundschuh J., Nath B., Nicolli H.B., Gutierrez M., Reyes-Gómez V.M., Núñez D., Martín-Domínguez I.R. and Sracek O. (2013). Cooccurrence of arsenic and fluoride in groundwater of semi-arid regions in Latin America: Genesis, mobility and remediation. J. Hazard Mater. 262, 960-9.

DOI: 10.1016/j.jhazmat.2012.08.005

Arreguín-Cortéz F.I., Chávez Guillén R. and Soto Navarro P.R. (2010). Una revisión de la presencia de arsénico en el agua subterránea de México. Rev. Tlaloc 45, 1-11

Bartolotta S.A., Pacskowski M.G., Hick A. and Carballo M.A. (2010) Micronuclei assay in exfoliated buccal cells from individuals exposed to arsenic in Argentina. Arch. Environ. Contam. Toxicol. 61 (2), 337-43.

DOI: $10.1007 / \mathrm{s} 00244-010-9607-1$

Basu A., Ghosh P., Das J.K., Banerjee A., Ray K. and Giri A.K. (2004). Micronuclei as biomarkers of carcinogen exposure in populations exposed to arsenic through drinking water in West Bengal, India: a comparative study in three cell types. Cancer Epidemiol. Biomarkers Prev. 13 (5), 820-7.

Bonassi S., Znaor A., Ceppi M., Lando C., Chang W.P., Holland N., Kirsch-Volders M., Zeiger E., Ban S., Barale R, Bigatti M.P., Bolognesi C., CebulskaWasilewska A., Fabianova E., Fucic A., Hagmar L., 
Joksic G., Martelli A., Migliore L., Mirkova E., Scarfi M.R., Zijno A., Norppa H. and Fenech M. (2007). An increased micronucleus frequency in peripheral blood lymphocytes predicts the risk of cancer in humans. Carcinogenesis 28 (3), 625-31.

DOI: $10.1093 /$ carcin/bgl177

Celik I., Gallicchio L., Boyd K., Lam T.K., Matanoski G., Tao X., Shiels M., Hammond E., Chen L., Robinson K.A., Caulfield L.E., Herman J.G., Guallar E. and Alberg A.J. (2008). Arsenic in drinking water and lung cancer: a systematic review. Environ. Res. 108 (1), 48-55. DOI: 10.1016/j.envres.2008.04.001

Chakraborty T., Das U., Poddar S., Sengupta B. and De M. (2006). Micronuclei and chromosomal aberrations as biomarkers: a study in an arsenic exposed population in West Bengal, India. Bull. Environ. Contam. Toxicol. 76 (6), 970-6. DOI: 10.1007/s00128-006-1013-z

Chakraborty T. and De M. (2009). Clastogenic effects of inorganic arsenic salts on human chromosomes in vitro. Drug Chem. Toxicol. 32 (2), 169-73. DOI: 10.1080/01480540802594509

Coronado-González J.A., Del Razo L.M., García-Vargas G., SanMiguel-Salazar F. and Escobedo-de la Peña J. (2007). Inorganic arsenic exposure and type 2 diabetes mellitus in Mexico. Environ. Res. 104 (3), 383-9.

DOI: 10.1016/j.envres.2007.03.004

EPA (2006). A framework for assessing health risks of environmental exposures to children. Environmental Protection Agency [online]. https://cfpub.epa.gov/ ncea/risk/recordisplay.cfm?deid=158363 08/09/16.

Ghosh P., Basu A., Singh K.K. and Giri A.K. (2008). Evaluation of cell types for assessment of cytogenetic damage in arsenic exposed population. Mol. Cancer. 7, 45. DOI: 10.1186/1476-4598-7-45

Gonsebatt M.E., Vega L., Salazar A.M., Montero R., Guzmán P., Blas J., Del Razo L.M., García-Vargas G., Albores A., Cebrián M.E., Kelsh M. and OstroskyWegman P. (1997). Cytogenetic effects in human exposure to arsenic. Mutat. Res. 386 (3), 219-28.

Holland N., Fucic A., Sram R. and Kirsch-Volders M. (2011). Micronuclei in neonates and children: effects of environmental, genetic, demographic and disease variables. Mutagenesis 26 (1), 51-6.

DOI: 10.1093/mutage/geq064

Huang C.F., Chen Y.W., Yang C.Y., Tsai K.S., Yang R.S. and Liu S.H. (2011). Arsenic and diabetes: current perspectives. Kaohsiung J. Med. Sci. 27 (9), 402-10. DOI: 10.1016/j.kjms.2011.05.008

IARC (2012). Arsenic and arsenic compounds. Monograph. International Agency for Research of Cancer [online]. http://monographs.iarc.fr/ENG/Monographs/ vol100C/mono100C-6.pdf 08/09/16

SSA (1994). Norma Oficial Mexicana NOM-127SSA1-1994. Salud ambiental, agua para uso y consumo humano-límites permisibles de calidad y tratamientos a que debe someterse el agua para su potabilización. Secretaría de Salud. Diario Oficial de la Federación. 20 de junio de 2000.

Montero R., Araujo A., Carranza P., Mejía-Loza V., Serrano L., Albores A., Salinas J.E. and Camacho-Carranza R. (2007). Genotype frequencies of polymorphic GSTM1, GSTT1, and cytochrome P450 CYP1A1 in Mexicans. Hum. Biol. 79 (3), 299-312.

DOI: $10.1353 /$ hub.2007.0037

Martínez V., Creus A., Venegas W., Arroyo A., Beck J.P., Gebel T.W., Surrallés J. and Marcos R. (2005). Micronuclei assessment in buccal cells of people environmentally exposed to arsenic in northern Chile. Toxicol. Lett. 155 (2), 319-27. DOI: 10.1016/j.toxlet.2004.10.007

Neri M., Fucic A., Knudsen L.E., Lando C., Merlo F. and Bonassi S. (2003). Micronuclei frequency in children exposed to environmental mutagens: a review. Mutat. Res. 544 (2-3), 243-54.

Rocha-Amador D., Navarro M.E., Carrizales L., Morales R. and Calderón J. (2007). Decreased intelligence in children and exposure to fluoride and arsenic in drinking water. Cad. Saude Publica. 23 (4), S579-87.

States J.C., Srivastava S., Chen Y. and Barchowsky B. (2009). Arsenic and cardiovascular disease. Toxicological Science 107 (2), 312-323.

DOI: $10.1093 /$ toxsci/kfn236

Tapio S. and Grosche B. (2006). Arsenic in the aetiology of cancer. Mutat. Res. 612 (3), 215-46.

DOI: $10.1016 /$ j.mrrev.2006.02.001

Thomas P., Holland N., Bolognesi C., Kirsch-Volders M., Bonassi S., Zeiger E., Knasmueller S. and Fenech M. (2009). Buccal micronucleus cytome assay. Nat. Protoc. 4, 825-37. DOI: 10.1038/nprot.2009.53

Tolbert P.E., Shy C.M. and Allen J.W. (1991). Micronuclei and other nuclear anomalies in buccal smears: a field test in snuff users. Am. J. Epidemiol. 134 (8), 840-850. 